\title{
Balancing focal species, recreation and biodiversity in mountain coal mine closure planning - Alberta, Canada
}

\author{
J.L. Kansas HAB-TECH Environmental Ltd., Canada
}

M.D. Symbaluk Teck Resources Limited, Canada

\begin{abstract}
Coal extraction in the Coal Branch region of Alberta, Canada has occurred since 1911 with surface mining dominating as of the 1940s. Coal mining in this mountain/foothills landscape now occurs in a multiple land use context along with oil and gas exploration and production, timber harvest, aggregate mining, big game hunting/guiding/outfitting, fur trapping, recreational All Terrain Vehicle (ATV) use, fishing, camping and other outdoor recreational pursuits. Currently, there are three surface coal mines in various stages of active mining, reclamation and closure in the upper elevations of the Coal Branch region. Mining has taken place within an increasingly stringent regulatory framework. In the mid-1990s, application was made for the Cheviot mine project. It's close proximity to Jasper National Park and heightened cumulative effects assessment requirements resulted in a ground-breaking series of public hearings, legal proceedings and two federal-provincial Joint Review Panels. Focal wildlife species, with particular emphasis on large carnivores (grizzly bears) and ungulates (elk, bighorn sheep), were a major aspect of the Cheviot environmental impact assessments and subsequent research/monitoring. The Cheviot mine was approved in 2004 with the first of a series of mine licenses required through the phased mine development. A land use planning process (LUP) is on-going for the end land use closure planning of two older coal mines (Luscar and Gregg River) located near the Cheviot Mine. This process is being informed by on-going ecological research and monitoring at all three mines. The issues and discussions surrounding the LUP are in turn informing the Cheviot Mine permit application process. Three over-arching end land use goals dominate the current mine closure planning debate. They include: 1) maintaining and enhancing focal species habitat and populations as per the original Cheviot project mandate; 2) preserving either pre-disturbance or modified recreational land use opportunities; and, 3) approximating pre-disturbance native biological diversity conditions. This paper discusses challenges and lessons learned over a 15-year period concerning the balancing of these three primary end land use goals.
\end{abstract}

\section{Introduction}

\subsection{Early coal mining history}

Alberta's Coal Branch region, located in the Rocky Mountains and foothills of west-central Alberta (Figure 1), served an important historic role in providing the steam energy requirements of western Canada's emerging northern rail transportation sector. A branch line from the transcontinental Grand Trunk Pacific railway was constructed in 1911. The line started in Edson and terminated in the high subalpine elevations of Mountain Park, where mining began in 1912. The Coal Branch was a regionally significant producer of coal with a peak production of 1.5 million tons in 1929. This represented about 22 percent of the total coal production in the province of Alberta at that time. In the early decades, most of the coal was extracted using conventional underground methods. Surface mining was introduced in the 1940s, during which time production peaked. Operations ended in 1950 when the rail industry switched to diesel. The mining town of Mountain Park, which had reached a population of 1,500 residents, also closed at that time. Interest in the area's coal reserves were rekindled in the late 1960's with the rise in global demand for metallurgical coal, a staple commodity required in the production of steel. To meet this demand, the Luscar Mine was re-opened by Cardinal River Coal Ltd. (CRC) in 1969, and concurrently a coal exploration program was initiated at the Cheviot property, near Mountain Park. Between 1969 and 1971, 450 test holes were drilled to evaluate the Cheviot property, and with subsequent drilling, resources were further defined. In 1976, with a downturn in world coal markets, CRC determined that a second coal mine in the area would not yet be feasible, and further exploration was put on hold. 


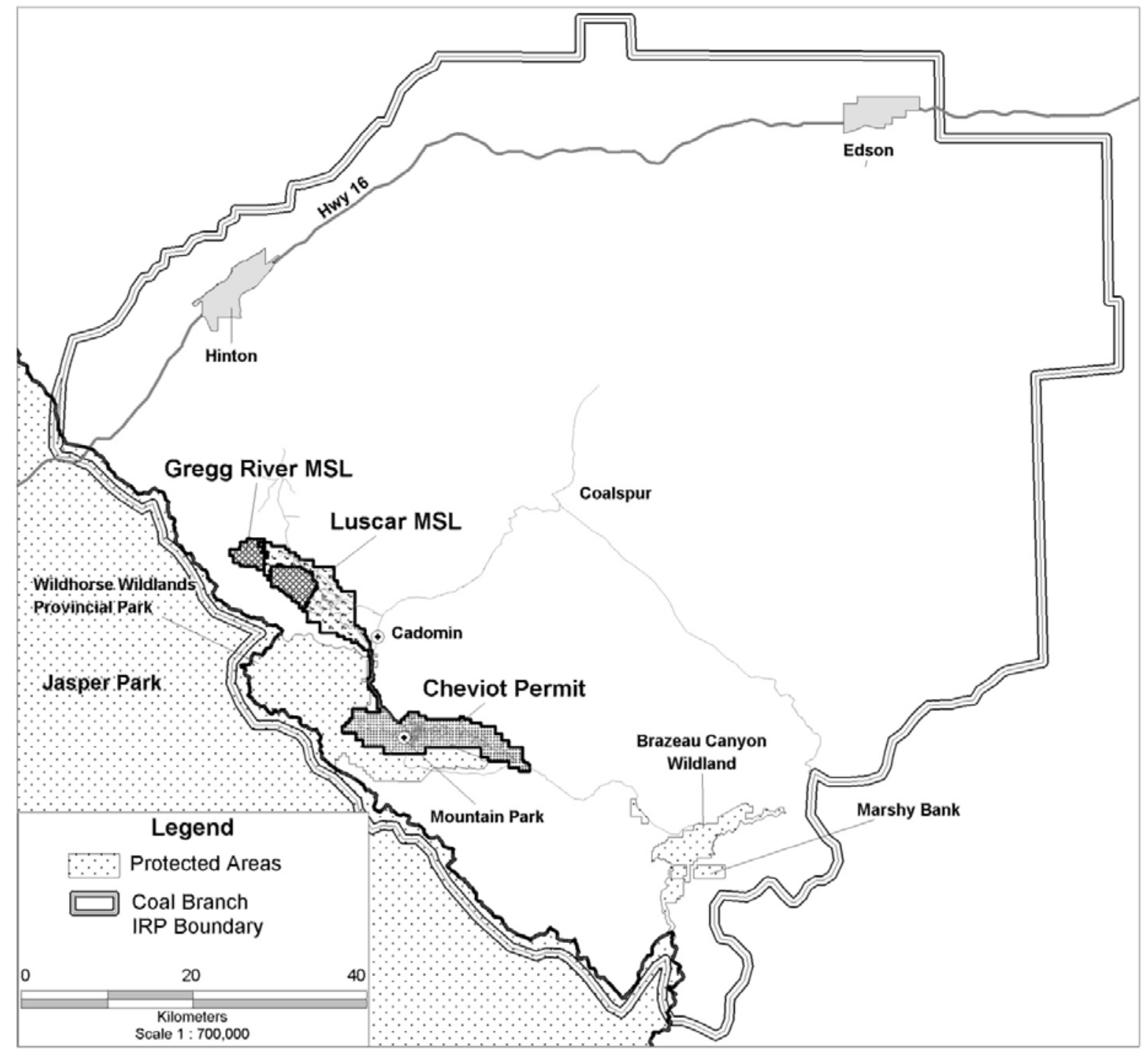

Figure 1 The Coal Branch Region of west-central Alberta showing Mine Permits and MSLs

\subsection{Recent coal mining history}

In the 1980s, the results of CRC's long-range planning indicated a need to develop replacement coal resources for the Luscar Mine. A Preliminary Disclosure document was submitted to the Province for the Cheviot Project and was accepted in principle in 1985. In 1991, drilling programs and preliminary environmental and engineering studies were initiated. After extensive regulatory and stakeholder involvement, CRC submitted an application for a provincial mine permit and federal Canadian Environmental Assessment Agency (CEAA) approval in 1996. A Joint Federal/Provincial Review Panel was formed and, later in 1996 and early 1997, public hearings were held. In late 1997, the Cheviot Mine was given conditional approval and CRC began detailed planning to commence development of the first mine pits. Alberta Environmental Protection and Enhancement Act (EPEA) Approval \#46972 was received in September 1998. At the same time, an appeal to federal courts by a coalition of environmental groups fundamentally opposed to the project was successful and the mine permit approval was withdrawn. CRC submitted a second application in 1999 to address deficiencies noted in the federal court's decision. In 2000, the Cheviot application was heard a second time by the Joint Review Panel and a second approval was issued later that year. However, by this time, world metallurgical coal markets warranted the proponent's delay of the Cheviot development plans. 
In late 2003, with coal markets rebounding, mine development plans were refined for the Cheviot Mine, and in early 2004, the leaseholder announced their intention to proceed with development of that project. Approvals were received to proceed with development of the first pit sequences in the Cheviot Creek pit and construction of a private haul road to access the reserves and move coal back to the Luscar mine for processing. The first load of coal was hauled to the Luscar Mine processing plant in October 2004. Approvals issued were subject to yet another public hearing in front of the Alberta Environmental Appeals Board in early 2005. These approvals were upheld. In 2006, EPEA approvals were amended to include the next phase of Cheviot with the Prospect development and associated infrastructure. Most recently, approvals have been received in 2010 for the third phase of development - the McLeod-Harris pits. Since mining commenced in 2004, the Cheviot Mine, operated by Teck's Cardinal River Operations (CRO), has produced over 10 million cubic tones of coal and has moved over 100 million BCM of waste rock (to the end of 2010), from both Cheviot Creek and Prospect development phases. A total of 655 ha have been disturbed and 14 ha are currently in the early stages of reclamation. Predevelopment activity including soil salvage is underway in McLeod-Harris for mining in mid-2011.

In Alberta, a surface land disposition, referred to as a mineral surface lease (MSL), is required from the provincial government to carry out coal mining. Throughout the life cycle of mining land use, MSL lands remain under a restricted public access management regime. These MSL dispositions are retained within the permit area, as the mine development advances, and include both those areas under active mine influence as well as those areas undisturbed but immediately adjacent. The current Cheviot MSL comprises 1602 ha. Within this surface disposition, most of the over 900 ha of currently undisturbed area will not be disturbed through the life of mine plan. The Cheviot Mine permit comprises some 7,100 ha. Within this permit area, planned disturbance over the life of the Cheviot project is approximately 2,600 ha. This activity will follow a phased mine development over the 25 years with progressive reclamation following pit and dump completion.

Open pit mining in the Luscar and Gregg River mines started in 1969 and 1983, respectively. The Gregg River Mine was closed in 2000 and active mining in the Luscar Mine completed in 2004 with the shift to the Cheviot Mine operations. The combined Luscar/Gregg mine MSL area covers nearly 7,100 ha of which a total of 3,600 ha was mined or disturbed and 3,400 ha undisturbed. To date, all of the Gregg River and approximately $50 \%$ of the Luscar disturbed areas have been subject to reclamation activity.

\subsection{Introducing primary mine closure challenges}

In the 15+ years since the first Cheviot project approvals were sought, there have been numerous scientific and social challenges, demands and surprises associated with mine closure planning and related assessment and research. Conserving regional grizzly bear populations was at the forefront of the impact assessments and mine closure debate from the beginning (Logan and Ferster, 2002; NSERC, 2000). It was recognised by regulators, scientists and the public that this vulnerable and wide-ranging species would serve as a useful focal and umbrella species (Carroll et al., 2001; Roberge and Angelstam, 2004) against which to measure the success of mine planning, as well as regional land use planning. The focus on the grizzly bear and its landscape requirements brought with it related issues and challenges. Other focal species such as bighorn sheep were already known to benefit from habitat development through mine reclamation in this region resulting in significant population increases (MacCallum and Geist, 1995). Big game hunting and outfitting is a major recreational activity in the Cheviot Mine region and the interrelationships between elk, sheep, grizzly bears and hunters proved to be a persistent issue particularly relating to access onto mined lands and surrounding areas. Other recreational pursuits such as hiking, wildlife viewing, ATV riding, mountain biking, equestrian, fishing and camping are also popular in the region and mined lands (especially following closure) could offer opportunities for each of them. Competition for reclaimed mined lands between focal species and a variety of recreationists would require innovative planning. Finally, the stark contrast in the nature and era of mine reclamation at the Luscar/Greg River Mine versus the more contemporary requirements of the Cheviot Mine raised the issue of the role of biodiversity in mine reclamation.

This paper documents some of the main issues and challenges associated with mine planning and closure in the mountains and upper foothills of the Coal Branch region of Alberta from the mid 1990s to present. Industry and regulator approaches to addressing issues pertaining to focal wildlife species management, recreational land use and biodiversity conservation form the basis of discussion. The paper ends with some 
lessons learned and advice concerning the potential risks associated with attempting to balance competing end land uses in mine closure.

\section{$2 \quad$ Key closure planning issues and mining industry responses}

\subsection{Focal wildlife species}

The Coal Branch Sub-Regional Integrated Resource Plan (IRP) was completed and approved in 1990. It provides a planning framework for the management and use of public land and resources within the region surrounding the mines. The Luscar/Gregg and Cheviot Mine permit areas are located within lands zoned as either "prime protection", "critical wildlife", "general recreation" or "multiple use". The Luscar/Gregg Mines are located at lower elevations than the Cheviot Mine and are dominated by closed coniferous lower subalpine forest with small patches of grasslands occurring on ridge tops and steep south-facing slopes. These lands were zoned primarily as 'multiple use' and prior to mining and reclamation offered limited high quality habitat for elk, bighorn sheep and grizzly bear and other large carnivores. The Cheviot Mine permit area is located at higher upper subalpine elevations than the Luscar/Gregg mine area. Terrain is more rugged on Cheviot lands and vegetation is open and varied, offering more favourable foraging opportunities for ungulates (mainly elk, moose and deer) and grizzly bears. As such, over $80 \%$ of the Cheviot Mine permit area was classified as 'critical wildlife' in the Coal Branch IRP. Objectives of the IRP included increasing the elk population from 90 to 200 animals and maintaining the existing bighorn sheep population. Ironically, no specific objectives were set for grizzly bear populations or habitat in the IRP, due to insufficient regional knowledge of grizzly bears.

\subsubsection{Enter the grizzly bear}

Scientific understanding of grizzly bear population status and response to human land use was very limited at the time of the application process for the Cheviot Mine. No empirical studies of grizzly bear response to active or reclaimed mine lands were available at the time of the 1996 and 1999 impact assessments and associated Joint Review Panel decisions. As such, EIA practitioners were forced to rely on studies from other jurisdictions and their expert opinion to predict the nature and significance of grizzly bear response to the effects of mining and reclamation. Inductive habitat effectiveness (Weaver et al., 1987) and security area (Mattson, 1993) models were applied to predict grizzly bear occurrence and response to mining and cumulative land use. The zones of influence and disturbance coefficients for these models were based on research conducted in the northwestern United States.

During the environmental impact assessment and mine permit application process, grizzly bears were identified as a key species due to their large area habitat requirements and their assumed susceptibility to negative impacts from the mine's activities, as well as from regional, cumulative land uses. It was the general consensus that if sufficient habitat for grizzly bears were maintained, this would serve to protect many other species with smaller area requirements. The environmental and cumulative effects assessments conducted for the proposed Cheviot Mine (BIOS, 1996; Kansas and Collister, 1999) predicted that project implementation would create significant adverse effects to sensitive species of mammalian carnivores, particularly the grizzly bear. It was concluded, that even without the mine, the cumulative impact of other industrial and recreational activities in the region would have significant negative impacts on grizzly bears (BIOS, 1996). Both Joint Panels concluded that the Cheviot project itself would essentially eliminate (for $100+$ years) grizzly bear habitat within the disturbance footprint, prevent bear movement across the development footprint, and change public access in ways that would result in direct grizzly bear mortality. The Joint Panels also concluded that without mitigation, the Cheviot project would result in significant adverse effects on grizzly bears and that there would be a significant risk of regional cumulative effects with or without the Project.

To mitigate cumulative land use effects on sensitive carnivores, including grizzly bears, the mining proponent proposed a Carnivore Compensation Program (BIOS, 1996; CRC, 1996; Logan and Ferster, 2002). This program recommended a multi-stakeholder approach to study, manage and monitor human land use effects on carnivores in the region surrounding the mine. The Joint Review Panel embraced this approach and as a condition of approval required the proponent to "...act as a catalyst in generating multi-stakeholder support for the implementation of the carnivore compensation plan and that CRC be required to contribute to 
a fund for the purposes of carnivore habitat mitigation" (EUB-CEAA, 2000). This led to the development of the Grizzly Bear Conservation in the Yellowhead Ecosystem - A Strategic Framework (2000), a joint initiative between Alberta Environment and Parks Canada, Jasper National Park. This framework proposed actions and cooperative working arrangements considered necessary to manage cumulative land use impacts in a $41,000 \mathrm{~km}^{2}$ region roughly cantered on the Cheviot mine permit area. The primary concern was the need for an ongoing partnership between the two governments “...to ensure trans-boundary environmental effects which would threaten the long-term persistence of grizzly bear populations in Jasper National Park are mitigated" (Parks Canada, 1997).

A central component of the Strategic Framework was a long-term field research program designed to more fully understand and support the management of suitable landscape conditions for grizzly bear population persistence. The research was funded by an ever growing list of stakeholders and was administered initially by the Foothills Model Forest in Hinton, Alberta. This "Cheviot-stimulated" empirical research program would usher in a new era of understanding (and surprises) concerning grizzly bear status and response to mining and cumulative land uses.

\subsubsection{The empirical era begins- 1999 to 2005}

Field studies for the Foothills Model Forest Grizzly Bear Research Project (FMFGRP) were initiated in the spring of 1999. The original study area was $5,352 \mathrm{~km}^{2}$ in size and was cantered approximately on the Cheviot Mine permit area $\left(71 \mathrm{~km}^{2}\right)$ with about one-third occurring in Jasper National Park. By 2005, Global Positioning System (GPS) radio-collars had been placed on 78 different grizzly bears and the study area had expanded to $9,800 \mathrm{~km}^{2}$. Support for the study was extensive, resulting in over 60 funding partners by 2005 . The FMFGRP was the first of its kind in Alberta to utilise GPS radio-collars for grizzly bear research. GPS collars on a 4-hour location capture duty-cycle allowed researchers to accumulate multiple tens of thousands of accurate locations of grizzly bears. The volume and frequency of this data coupled with advances in GIS mapping technology and statistical techniques facilitated empirical approaches directed toward more clearly understanding grizzly bear response to natural and anthropogenic landscape conditions.

The first five or six years of grizzly bear research (1999 to 2004) were conducted mainly in the region surrounding the Cheviot Mine. A wide range of studies resulting in peer reviewed publications were completed including: diet, nutrition and body condition; den site selection; habitat mapping by remote sensing; landscape change analysis; population demographics; movement; habitat use; effects of clearcut logging; and, effects of seismic lines and roads. Resource selection function (RSF) models were used extensively to analyse habitat selection and to assess the effects of industrial activity and footprint on grizzly bear habitat use, movement and mortality. Human land use parameters analysed for their effects on grizzly bears using RSF included clearcuts, seismic lines, pipelines, wells sites, roads and trails. Natural land use parameters included land cover type, riparian areas, topographic ruggedness, forest age, solar energy input (slope/aspect), and edge distance (Linke, 2003; Ritson-Bennet, 2003; Nielsen et al., 2004).

The mining industry in the Cheviot/Luscar region noticed that the effects of mining and mine reclamation were absent from this impressive suite of grizzly bear studies. They also noted that the first generation of RSF models was resulting in maps that identified reclaimed mines as either 'non-habitat' or areas of heightened mortality risk. This contrasted markedly with the long-term observations and mortality databases kept by the mining companies. In early 2005, CRO requested the FMFGRP use their extensive inventory and research data from 1999 to 2004 to summarise current knowledge and understanding of grizzly bear use of the Cheviot (pre-mining), Luscar and Gregg River Mine permit areas. The stated objectives of this study were: 1) to establish pre-development baseline grizzly bear use data in the Cheviot Mine area; and, 2) to provide insight into grizzly bear use in and adjacent to active and reclaimed open pit coal mines. A final report was released in June of 2005 (Stevens and Duval, 2005). This study and a re-analysis by Kansas (2005) provided some major surprises and served to stimulate a significant change in the nature and scale of subsequent grizzly bear research in the Cheviot/Luscar region.

\subsubsection{Digging deeper-grizzlies, ungulates and mines}

The approach taken by Stevens and Duval (2005) was to assess various aspects of grizzly bear ecology in the Cheviot permit area (pre-mining), as well as in the actively mined and reclaimed Gregg/Luscar Mine permits. The sub-set of data used to conduct these assessments was collected over the same 6-year period 
(1999 - 2004) as part of the larger FMFGRP. The mine permit study areas were equally sized (Cheviot and Gregg/Luscar - both approximately $71 \mathrm{~km}^{2}$ ) and located (at their centres) approximately $25 \mathrm{~km}$ apart. Each study area was oriented along a similar directional axis and both occurred in the Rocky Mountain Front Ranges dominated by Subalpine vegetation.

The authors targeted grizzly bears whose annual home ranges overlapped or bordered each of the two study areas. A total of 7 individual female and 8 individual male grizzly bears utilised habitat within the Cheviot permit area from 1999 to 2004. During that same time period, the annual home ranges of 8 individual female and 8 individual male grizzlies overlapped with the Gregg/Luscar permit block. Data from these bears and their home ranges were used to assess grizzly bear ecology separately for each study area. A small number of bears belonged to both study areas. Aspects of grizzly bear ecology assessed included home range size and fidelity, body condition, blood chemistry (genetic relatedness), mortality, diet, den site selection, movement (including road crossings) and reproduction. Identical analysis procedures were used for each study area and for the same time period.

A number of unexpected findings were discovered by comparing various ecological/biological measures for grizzly bears using the mined Gregg/Luscar and the un-mined Cheviot permit areas (Stevens and Duval, 2005; Kansas, 2005). These findings all, but completely contradicted the nature and magnitude of many of the assumed impacts from the Cheviot impact assessments as well as the RSF-based model results from the Foothills Model Forest study. When compared to data from the un-mined Cheviot permit area, grizzly bears using the mined and partially reclaimed Gregg/Luscar permit block occurred more frequently in the permit area, had smaller female home ranges (indicating higher productivity), supported significantly higher body condition indices for both sexes, denned more frequently within the mine permit area, and ingested significantly more high-energy animal protein (i.e., elk and bighorn sheep) and herbaceous forage. Grizzly bears in the Gregg/Luscar area also demonstrated similar cub production and home range fidelity as did bears in the Cheviot area. Bears moved freely through much of the Gregg/Luscar mine permit area in spite of active mining.

On balance, the partially reclaimed Gregg/Luscar Mine areas appeared to match and perhaps surpass the Cheviot area with respect to measures that might positively influence grizzly bear reproduction. The fundamental driver of grizzly bear response to reclaimed mine lands were two other focal wildlife species elk and bighorn sheep. Prior to mining, very few elk and bighorn sheep resided full-time in the Gregg/Luscar permit areas primarily because of the shortage of extensive grasslands and escape terrain. As of 2004, a total of 833 bighorn sheep were counted on the Gregg/Luscar Mine permit block. The highest one-day count of elk occurring on the Gregg/Luscar mine block increased steadily from 2 in 1990 to 156 in 2002. Few ungulate winter ranges in Alberta support the kind of combined densities observed for these two ungulate species in the Gregg/Luscar permit block. Mining and reclamation in both the Luscar and Gregg River permit areas had resulted in removal of tree canopies, leading to increases in availability of high energy herbaceous plant material (clover, thistles, legumes) and a tremendous increase in digestible protein for grizzly bears in the form of ungulates. These ungulates had in turn, responded to increased forage and escape cover associated with mine reclamation.

In an attempt to more fully understand these preliminary findings, CRO decided take a more focused approach to grizzly bear research in the Cheviot/Luscar area. Two mining industry-specific graduate research studies were funded from 2006 to 2010. The first study (Symbaluk, 2008) tested the accuracy of habitat effectiveness (BIOS, 1996) and RSF (Nielsen, 2007) modelling results on the Luscar/Gregg mine permit areas using existing FMFGBRP grizzly bear location data. It was concluded that outputs from both models were not predictive of grizzly bear occurrence on mined landscapes. Bears were found to use reclaimed mines to a much greater extent than predicted by regional habitat models. Symbaluk (2008) also closely followed two radio-collared grizzly bears for two years. Grizzly bear movement paths prior to and during Cheviot Mine disturbance, determined that mining land use (reclaimed or active) did not present significant landscape or regional barriers to grizzly bears. A second intensive research study by the University of Alberta began in 2008 and is being finalised in 2011. This study monitored 10 GPS-collared grizzly bears in the immediate vicinity of the Cheviot and Luscar/Gregg mines. Objectives of the study were to more fully understand movements before, during and after mining as well as foraging and resting/bedding behaviour of grizzly bears along movement paths. Details of some of the results of this study are found in these same conference proceedings. 


\subsection{Recreational land use}

Under private disposition of a MSL by the mining company, public access is generally closed, with the exception of limited designated access trails for recreational use, with the entire MSL area closed to hunting. Hence, reclaimed areas of mines that offer high quality habitat for a focal species do so in the relative absence of human-caused mortality risk or harassment. For example, in the almost 40 years of continuous open pit mining in the Coal Branch area, there are no records of any human-caused grizzly bear mortality on MSLs. The findings outlined in Section 2.1 and the hundreds of bighorn sheep, elk and deer utilizing the Luscar/Gregg mines are clear of evidence of the low mortality, high productivity status of reclaimed MSLs. There are however, uncertainties and serious challenges associated with maintaining the positive elements of post-mining landscapes for focal wildlife species, and particularly grizzly bear. Kansas (2005) noted that 7 of 16 of the grizzly bears with home ranges overlapping the Gregg/Luscar permit areas died from 1999 to 2004. Mortalities all occurred outside of the permit areas with all but one involving firearms. Two deaths were from legal hunting (which was terminated in Alberta in 2006). This contrasted with only one of 15 grizzlies using the more remote Cheviot area being killed (legal hunting). That adult male bear also used the Gregg/Luscar permit area. Kansas (2005) noted that population growth of grizzly bears is much less sensitive to changes in reproduction than to changes in survival. It would require a $15 \%$ improvement in reproductive output to reduce survival rate by $1 \%$ (Garshelis et al., 2005). Clearly, any gains in reproduction stimulated by mine-related habitat improvements would quickly be negated by the deaths of a very few individual bears.

Upon closure and decommissioning, reclaimed mined lands once again revert to the Province of Alberta. Symbaluk (2008) noted that it is after mine closure that grizzly bears are most vulnerable to potential increases in mortality associated with public access (e.g., mistaken identity kills, defence of life and property, illegal hunting). Without careful land planning and management, an attractive source for grizzly bears has potential to quickly become a mortality sink. In recognition of this potential, Teck (along with Coal Valley Resources and Alberta Sustainable Resource Development) promoted a multi-stakeholder land management planning (LMP) process specifically for the closure of the Luscar and Gregg River Mines. This on-going process engaged 18 stakeholders representing a variety of community of interests such as conservation, stewardship, non-motorised recreation, motorised recreation, commercial outfitting, hunting and eco-tourism. The process established a vision for the area that would see the continued conservation of the habitats and populations of wildlife supported by the post-mining reclamation. The plan accommodates a wide range of land uses including: hiking, wildlife viewing, photography, off-highway vehicle use, cross country skiing, mountain biking, equestrian, ecotourism, hunting, trapping, angling, and research/interpretive activities. All of these land uses are restricted in a manner that minimises impacts on focal wildlife species. Details of this planning process are found in these same conference proceedings.

Although closure of the Cheviot Mine is several decades away, Teck is required to design mitigation/reclamation measures to minimise impacts on focal wildlife species as part of individual pit development applications. The latest application (Harris-McLeod pit) applied some of the experience from the LMP to enhance pit closure planning. Learnings from the monitoring component of the Luscar/Gregg LMP will be progressively applied to individual Cheviot pit plans as they are completed.

\subsection{Biodiversity in reclamation}

Early reclamation of the Luscar and Gregg River Mines was dominated by a seed mix of agronomic cool season grasses and legumes characterised by winter hardiness and high drought resistance. Such plants were rapidly growing and slow to decompose, leaving excessive litter which hindered successful establishment of planted trees and resisted native plant colonization. Although the early agronomic seed mixes resulted in highly nutritious forage for bighorn sheep and elk, these mixes are falling out of favour in the last 10 to 15 years as regulatory requirements to restore native biological diversity have increased.

An ecological or "ecosystem management" approach was adopted for the Cheviot Mine conceptual reclamation plan (CRC, 1996). The mine disturbance area was sub-divided into Biophysical Reclamation Units (BRU) which supported similar ecological potential and end land use objectives. The initial seeding was planned to consist of the same grasses and legumes used in the Luscar mine's current (1996) seed mix which included 3 native plant species. Native tree and shrub plantings were planned two to four years after initial revegetation. The closure landscape envisioned a wide range of vegetation cover type/topographic 
combinations including upland and riparian shrublands, open and closed coniferous forests, and grasslands. Target species included elk/deer (assemblage), moose, bighorn sheep and grizzly bear with planting prescriptions developed for each species and BRU. Since the original Cheviot reclamation plan, Teck's adaptive management approach led to changes to the seed mixes that promote natural recovery and native species establishment. The ecological approach and targets have remained similar. The movement toward more natural recovery and less areas of agronomic/legume mix will likely result in a slower and less robust colonization of ungulates and a less attractive source of digestible protein for grizzly bears. It remains to be seen whether or not overall wildlife species diversity is enhanced by a greater emphasis on natural recovery and native plant establishment. Teck will continue to monitor wildlife use of reclaimed areas on a regular basis on both the Luscar and Cheviot mines.

\section{$3 \quad$ Lessons Learned}

The story of mountain mines in the Alberta Coal Branch and especially the Cheviot Mine offer several lessons learned concerning mine closure and planning. Below, we list some of these with advice:

- Be wary of predictive regional models and whenever possible, put resources into actual empirical studies to inform mine planning, assessment and closure.

- Avoid underestimating the resilience and tolerance of wildlife species and their attraction to quality reclaimed habitat.

- In multiple land use scenarios, try to clearly understand your resource development project's own incremental impacts before getting too deeply into cumulative land use planning and assessment.

- Mines exert considerable control over other land uses within their actively managed lands, which lessens complicated and un-predictable cumulative effects. That influence on land management may be lost after closure. Further, cumulative impact potential within the former mine permit may become very complex following closure.

- Mines at closure may not be able to maximise all values for all desired land uses (e.g., maximizing biodiversity lessens focal species forage quality). Certain values of the land may be more vulnerable than others and difficult land use restrictions may have to be achieved.

- Conditions at mine closure will probably not be able to optimise benefits for focal species, recreational users and biodiversity. Establish clear objectives as to dominant end land uses and utilise multi-stakeholder forums to openly explore and evaluate potential trade-offs of different management decisions.

\section{References}

BIOS Environmental Research and Planning Associates Ltd. 1996. Cheviot Mine Project. Specific and cumulative environmental effects analysis of mammalian carnivores. 122 pp. In: Cardinal River Coals Ltd. 1996. Cheviot Mine Project application. February 1996. (Appendix 34). Hinton, AB.

Carroll, C., R. F. Noss, and P.C. Paquet. 2001. Carnivores as focal species for conservation planning in the Rocky Mountain region. Ecological Applications 11:961-980.

CRC (Cardinal River Coals Ltd.). 1996. Cheviot Mine Project application. February 1996. 10 Volumes. Hinton, AB.

EUB-CEAA (Alberta Energy and Utilities Board-Canadian Environmental Assessment Agency). 2000. Report of the EUB-CEAA Joint Review Panel, Cheviot Coal Project, Mountain Park Area, Alberta (EUB Decision 97-8). June 1997. 161 pp. Alberta Energy and Utilities Board, Calgary/Canadian Environmental Assessment Agency, Hull.

Garshelis, D.L., M.L. Gibeau, and S. Herrero. 2005. Grizzly bear demographics in and around Banff National Park and Kananaskis Country, Alberta. Journal of Wildlife Management 69:277-297.

Kansas, J. L. 2005. Grizzly bears and mining in the Cheviot region: Retrospective analysis. Prepared for Cardinal River Operations) by URSUS Ecosystem Management Ltd., Calgary, Alberta. 29 pp.

Kansas, J.L. and Collister, D.M. 1999. Cumulative effects assessment for grizzly bears: Supplemental information Cheviot Mine Project. Prep. for Cardinal River Coals Ltd. by URSUS Ecosystem Management Ltd., Calgary, Alberta. 87 pp. 
Linke, J. 2003. Using Landsat TM and IRS imagery to detect seismic cutlines: Assessing their effects on landscape structure and on grizzly bear (Ursus arctos) landscape use in Alberta. M.Sc. Thesis, Department of Geography, University of Calgary, Calgary, Alberta, Canada.

Logan, B., \& Ferster, R. (2002). Cumulative environmental effects assessment and management: the Cheviot mine experience. In A. Kennedy (Ed.), Proceedings from Alberta Society of Professional Biologists Symposium 2000. Cumulative environmental effects management-Tools and Approaches (pp. 17-30). Edmonton, AB: Alberta Society of Professional Biologists.

MacCallum, N. B., and V. Geist - 1995 Reclamation of a mountain coal mine: designing habitat for bighorn sheep. Chapter 7, 152-195 in Nigel, J. R. Allan (ed). Mountains at risk, current issues in environmental studies. Manohar, New Delhi. 296pp.

Mattson, D.J. 1993. Background and proposed standards for managing grizzly bear habitat security in the Yellowstone Ecosystem. Cooperative Park Studies Unit. University of Idaho. Missoula, MT. 8 pp.

Nielsen, S.E., M.S. Boyce, and G.B. Stenhouse. 2004. Grizzly bears and forestry I: selection of clearcuts by grizzly bears in west-central Alberta, Canada. Forest Ecology and Management 199:51-65.

Nielsen, S.E. 2007. Seasonal resource selection function (RSF) models for grizzly bears in the Foothills Model Forest region of Alberta. Edmonton, AB: Conservation Analytics.

Northern East Slopes Environmental Resource Committee (NSERC) (2000) Grizzly bear conservation in the Alberta Yellowhead Ecosystem: A strategic framework. Publication No.T/519.Edmonton, AB: Alberta Environment.

Parks Canada 1997. Parks Canada submission to the Alberta Environmental Utilities Board - Cheviot Mine Project. January 1997. 41 pp.

Ritson-Bennet, R.A. 2003. Assessing the effects of a heli-portable 3D seismic survey on grizzly bear (Ursus arctos) distribution. M.Sc. Thesis, Department of Geography, University of Calgary, Calgary, Alberta, Canada.

Roberge, J.M., and P. Angelstam. 2004. Usefulness of the umbrella species concept as a conservation tool. Conservation Biology 18:76-85.

Stevens, S. and J. Duval. 2005. Ecology of grizzly bears in the Cheviot, Luscar and Gregg River mine areas (19992004). Submitted to Elk Valley Coal Corporation, Cardinal River Operations and Foothills Model Forest Grizzly Bear Research Project. 111 pp.

Symbaluk, M. 2008. Testing Landscape Modeling Approaches for Environmental Impact Assessment of Mining Land Use on Grizzly Bears (Ursus arctos horribilis) in the Foothills Region of West Central Alberta. Master of Science Thesis, Royal Roads University. 112 pp.

Weaver, J.L., R.E.F. Escano, and D.S. Winn. 1987. A framework for assessing cumulative effects on grizzly bears. Trans. 52nd N.A. Wildl. \& Nat. Res. Conf. $364-376$. 